7. New appliances, such as pertain to nursing the sick, including the methods of transportation and baths for the sick.

8. Apparatus (new) for hygienic purposes.

The Special Committee on "Exhibition" consists of the following gentlemen : Commerzienrath Paul Dörffel, H. Haensch, Director Dr. J. F. Holtz, Director Dr. L. Loewenherz, Regierungsrath Dr. J. Petri, H. Windler, and the Secretary-General of the Committee of Organization. The names of the associate members of the Exhibition Committee, as well as the names of the heads of departments, will be made known shortly ; also the conditions for exhibitors.

For applications for exhibits and information please address, Dr O. Lassar, Secretary-General, Bureau of the Tenth International Medical Congress, Berlin

N. W. Carlstrasse No. 19.

Please designate all mail matter relating to the Exhibition, "Exhibition Affairs," and also enclose a visiting card or card of the firm, on which the name and residence is plainly written or printed.

The Bureau is open for the present from 5-7 o'clock p.m.

The Committee of Organization of the Tenth International Medical Congress: Dr. Rudolf Virchow, President; Dr. E. von Bergmann, Dr. E. Leyden, Dr. W. Waldeyer, Vice-Presidents; Dr. O. Lassar, Secretary-General.

\title{
PROPOSED HOSPITAL FOR THE INSANE IN LONDON.
}

Since the Occasional Notes of the Quarter were written, the London County Council has discussed (March 11th) the report of the Special Committee, proposed for adoption by Mr. Brudenell Carter, and declined the proposal, but referred it to the Asylums Committee.

The amendment was moved by Dr. Cooper :-_" That the consideration of the report be adjourned for six months, and that it be referred to the Asylums Committee for consideration and report."

Dr. Bort seconded the amendment, and contended that there was universal dissatisfaction felt by medical men at the manner in which the Committee had selected their witnesses.

Mr. Austin urged the absolute necessity of the proposed hospital.

Mr. Parker Young said the important question of the locality of the hospital had not been discussed.

Mr. CARR-GoMm spoke generally in support of the recommendations.

Mr. MaRTineaU stated that the written communications of 55 superintendents were on the whole favourable to the scheme.

Mr. Brodenell Carter, in reply, said that the report of the Committee would not be forwarded by being referred to the Asylums Committee.

The amendment was submitted and carried, and afterwards agreed to as a substantive resolution.

CERTIFICATE OF EFFICIENCY IN PSYCHOLOGICAL MEDICINE. M.P.C. EXAMINATION.

The following candidates for this certificate passed the examination held at Bethlem Hospital, December 19th and 20th, 1889 :-

Boyd, James Paton, M.B., C.M.Glas.; Glasgow.

Bristowe, Hubert Carpenter, M.B.Lond., M.R.C.S.Eng.; Bethlem

Hospital.

EARLS, JaMes H., M.D.; London.

GaUdin, Francis NeEL, M.R.C.S.Eng., L.S.A.Lond ; Surrey.

PatTerson, ARThur Edward, M.B., C.M.Aberd.; London.

PtTcavin, JoHN JaMre, L.R.C.P., M.R.C.S.; London. 
Price, Arthor, M.R.C.S., L.S.A. ; Birmingham. Smyth, William Johnson, M.B., C.M.Edin.; Essex County Asylum. Wick haM, Gilbert Henry., B.A.Camb., M.R.C.S., L.S.A.; Bethlem Hospital. WilliaMs, D. J.; London.

The following are the written questions asked at the Pass Examination:-

Examiners :

Dr. Blandford and Dr. RAYNer.

Not more than Four of these Questions need be answered.

1. In what forms of insanity is suicide to be feared? What methods are chiefly adopted by patients, and what are the chief precautions to be taken?

2. What is meant by moral insanity? Give a case or cases from your experience.

3. What are the chief points to be observed in the examination of a person supposed to be insane? What facts would justify your signing or refusing to sign a certificate of insanity?

4. What treatment, regimenal, dietetic and medicinal, would you adopt in a case of stuporous insanity?

5. What are the post-mortem appearances in the brain of persons dying from acute melancholia?

6. What are the most common symptomatic prodromata of General Paralysis of the Insane, what conditions give them special significance, and how should such cases be treated?

The next examination will take place in July. For particulars apply to Dr. Fletcher Beach, Darenth Asylum, Dartford, Kent. For information respecting the Scotch and Irish examinations apply to Dr. Urquhart, James Murray Roval Asylum, Perth, Scotland; Dr. Conolly Norman, Richmond Asylum, Dublin, Ireland.

\section{Obituary.}

\section{DR. CARL WESTPHAL.}

On January 27, died at Constance, after a long and suffering illness, the Geheimrath, Professor Westphal.

His death is a heavy loss to science. Untiringly to his last moment has he laboured and worked, a prominent teacher of the University, an everywhere known, sought after, and esteemed physician, a true, never resting inquirer. Courageously has he continued on the field of battle until paralyzed by the long threatened sickness in body and mind. His name has an honoured sound not only in the ranks of his own department in his narrow circle of work, but far beyond the limits of his Fatherland has it extended. His great achievements will live in the kingdom of knowledge.

Carl Friedrich Westphal was born on the 23rd of March, 1833, the son of a well-known Berlin physician.

He studied from the year 1851 in Berlin, Heidelberg, and Zürich. In 1856 he passed the States examination. Returning from a scientific journey to Paris and Vienna, he was in 1858 appointed Assistant Physician in the department for small-pox at the Charité. After six months, he exchanged this position for that of an assistant physician in the section for insanity. In the year 1861 he qualified himself as "Docent" in psychology in the Berlin University, and from 1862 lectured with clinical instruction. Circumstances, however, induced him in 1868 to quit this department for a short time and devote himself to pure medicine. After the death of Griesinger, in 1869, he was appointed Professor Extraordinary and Directing Physician to the section for mental and nervous disorders. In 1871 he added to these two cliniques an ambulance clinique for nervous patients. In $187+$ he obtained his appointment as ordinary professor, and became a member of the Scientific Deputation of Public Medicine.

Westphal became a reformer in German psychiatry for the treatment of 